\title{
INDONESIAN TOURISTS’ PREFERENCES INFLUENCE OF CONSCIOUS AND UNCONSCIOUS MOTIVES
}

\author{
Ismayanti $^{1}$; Ina Djamhur ${ }^{2}$; Levyda ${ }^{3}$ \\ ${ }^{1,2,3}$ Universitas Sahid Jakarta, \\ Jln. Prof. Dr. Soepomo SH No.84 Tebet, Jakarta Selatan 12870 \\ maya.syahrial@gmail.com
}

\begin{abstract}
Motivation is the foremost variable to explain the travel preferences. It is identified that there are two motives of travelling: inner intention as the unconscious motives and outer magnet as the conscious motives. Inner intentions derive from tourists' mindset and push the actor to perform. Outer magnet is created by destination (tourism supplier, operators, hotelier etc.) to pull the customers. From 331 respondents in Jakarta (capital city) and Bandung as tourist generating regions in Indonesia showed that there are partial element of inner intention that encourage Indonesian to travel: religiousness and leisure time, and there are collective element of outer magnet that fascinate Indonesian tourist: cultural attraction and activities, outrange between domicile region and destination, and sophisticated amenities.
\end{abstract}

Keywords: motivation, travel, tourist domestic

\begin{abstract}
ABSTRAK
Motivasi adalah variabel penting untuk menjelaskan pilihan lawatan. Terdapat dua motivasi lawatan, yaitu intensi dalam diri individu sebagai motivasi bawah sadar dan magnet luar sebagai motivasi dalam sadar. Magnet luar termasuk tujuan (agen turisme, operator, pengurus hotel, dan sebagainya) untuk menarik pelanggan. Dari 332 responden di Jakarta (ibukota) dan Bandung sebagai kota tujuan turis di Indonesia menunjukkan bahwa terdapat elemen pemisah dari intensi dalam diri individu yang mendukung penduduk Indonesia untuk berlawatan adalah agama, waktu luang, dan ada unsur dari magnet luar yang mempesona turis domestic: aktivitas dan atraksi budaya, jarak antara lokasi domisili dan tujuan, dan fasilitas penunjang yang canggih.
\end{abstract}

Kata kunci: motivasi, lawatan, turis domestik 


\section{INTRODUCTION}

Tourism has function to fulfil the body, soul and intellectual desire by recreation and travelling. Tourism has become the member of human basic need; place it side by side with daily needs such as food, clothing and housing. The government of Indonesia put effort to perform those function by implementing the decree of designating public holiday and collective leave since 2008 . Collective leave was aimed to focus on work productivity and boosting the country's tourism industry. To compensate, they should work extra hours on other days.

As part of the government's efforts to attract visitors, the country improve awareness and build enhanced relations with potential destinations. Airport renovation is underway, together with facilities development from the private sector. As a result, the country witnessed significant growth of arrivals, albeit in business and leisure tourists. However, as the various tourism initiatives are to be followed by fast and effective improvements to buildings and the tourism infrastructure, revolutionary changes are seen in reverse. The decree was misinterpreted by the Indonesian. The designating public holiday and collective leave triggers more the outbound travel rather than domestic travel. The intentions to travel abroad raise, number of outbound trips and spending increase as shown in table 1.

Table 1 Fact of Domestic Travel and Outbound Tourist Indonesia Year 2001 To 2008

\begin{tabular}{|c|c|c|c|c|c|c|c|c|}
\hline Year & $\begin{array}{c}\text { Domestic } \\
\text { Traveller } \\
\text { (thousand) }\end{array}$ & $\square \searrow$ & $\begin{array}{c}\text { Total } \\
\text { expenditure } \\
\text { (billion IDR) }\end{array}$ & $\square \square$ & $\begin{array}{l}\text { Outbound } \\
\text { Tourist } \\
\text { (thousand( }\end{array}$ & $\square \searrow$ & \begin{tabular}{|c|} 
Total \\
spending \\
(million USD)
\end{tabular} & $\square \backsim$ \\
\hline 2001 & 103,884 & - & 58.7 & - & n.a & - & n.a & - \\
\hline 2002 & 105,379 & $1.4 \%$ & 68.8 & $14.7 \%$ & n. a & - & n. a & - \\
\hline 2003 & 110,030 & $4.2 \%$ & 70.9 & $2.9 \%$ & 3,769 & - & 3,450 & - \\
\hline 2004 & 111,353 & $1.2 \%$ & 71.7 & $1.2 \%$ & 4,270 & $11.7 \%$ & 3,672 & $6.0 \%$ \\
\hline 2005 & 112,701 & $1.2 \%$ & 74.7 & $4.0 \%$ & 4,806 & $11.2 \%$ & 3,286 & $-11.7 \%$ \\
\hline 2006 & 114,391 & $1.5 \%$ & 88.2 & $15.3 \%$ & 5,041 & $4.7 \%$ & 3,920 & $16.2 \%$ \\
\hline 2007 & 116,107 & $1.5 \%$ & 108.9 & $19.0 \%$ & 5,158 & $2.3 \%$ & 4,331 & $9.5 \%$ \\
\hline 2008 & 117,213 & $0.9 \%$ & 123.2 & $11.6 \%$ & 5,312 & $2.9 \%$ & 5,577 & $22.3 \%$ \\
\hline Average & & $1.7 \%$ & & $9.8 \%$ & & $6.5 \%$ & & $8.5 \%$ \\
\hline
\end{tabular}

Source: BPS (2009) and P2SDJ (2009)

The tourism industry is concerned with the fact, but yet they do not fully understand the cause. It is the purpose of the research to reveal the main motives of travelling: inner intention as the unconscious motives and outer magnet as the conscious motives of Indonesia tourist, so destination (operator, hotelier) should redesign and rebranding their product.

\section{Tourism and Domestic Tourist}

Tourism is a unique phenomenon. The concept of tourism is complicated and can be viewed from various perspectives. In Indonesia, the act number 10 years 2009 regarding Tourism has been ratified as follows: (1) tourism is the travel activities done by a person or a group to visit certain destination with the purpose of recreation, self-improvement or study the uniqueness of tourist attraction in temporarily; (2) a tourist is a person doing the travel activities; (3) tourism industry consists of various activities and supported by facilities and services, provided by community, entrepreneur, government and local government.

Tourism consists of three main elements (Cooper et.al, 2005), they are tourist, geographical element, and tourism industry. 


\section{Tourist}

from the trip.

He or she is the actor of travel activities and he or she obtains the experience and satisfaction

\section{Geographical Element}

The movement of tourist occurs in geographical coverage, they are (1) Tourist Generating Area (TGA) is the area where the tourist comes from and done their daily activities such as working, schooling and other basic needs, and it motivates them to get away from their routines; (2) Transit Area (TA), not all travelers stop-over or transit in a certain area but they definitely pass the transit region. Often the trip is diverted and ended in transit area, not in the tourist destination. Many transit countries perform its multi functions. They improve the accessibility and amenities to convert their function as from a hub to a destination; (3) Tourist Destination Region (TDR) is the finish line of the journey. It is the main of travel purpose. Destination is the raison d'être of the tourism, offers variety of excitement other than everyday activities. Each destination should have uniqueness and provide a certain level of quality to meet the tourist's expectation. The impact of tourism on economics, social culture and physical environment occur in destination, thus, it is important to have a proper tourism planning and strategic management.

\section{Tourism Industry}

The third element in tourism system is the industry itself. The industry provides products and services, attractions and activities, accessibilities and amenities. All make available to cater the need and wants (Gunn, 1995).

Based Indonesia tourism act, there are 13 key players in the tourism industry: tourist attraction, resort, transportation services, tour operators, food and drink establishment, accommodation, recreation and entertainment centre, conference organizers, exhibition organizer, incentive travel house, information centre, tourism consultant, tour guide, water recreation park and spa. UN-WTO (Gee, 1997) classify the tourism into two boundaries, they are domestic tourism and international tourism.

\section{Domestic Tourism}

Domestic or internal tourism is the activity of people visiting destinations within their own country's boundaries. It is the travel within one's country border line outside their home region with the purpose of pleasure, not working. The actor is called domestic tourist.

\section{International Tourism}

International or overseas tourism is the travel across one's country border line beyond their home region with the purpose of pleasure, not working. It is the activity of people visiting destinations outside their own country's boundaries. The actor is called international tourist. There are two types of international tourism; they are inbound tourism and outbound tourism.

Inbound or incoming tourism occurs when foreigners visit other country. It is the tourism of non-resident visitors within the economic territory of the country of reference. Incoming tourism is a valuable source of income for the country and the local economy, because they do not just spend money for the hotels and attraction, but also the benefit from the spending power of tourists to community. Money spreads out to benefit all sorts of local people. 
Outbound tourism. Outbound or outgoing tourism is the tourism of resident visitors outside the economic territory of the country of reference. As the opposite of inbound tourism, the outgoing tourism becomes a threat of one's country balance of payment. It is a leakage source of income for the country and the local economy, because they spend money for the meals and transportation to other nations.

\section{Tourist Motivation}

Motivation is a sum of behaviour process to achieve particular goals. Motivation derives from an attempt to fulfil needs on certain level of intensity. If someone has personal desire and he or she aware that his or her desire should be accomplished; there will be an inner force to act. Motivation emerges from expectation and it can be attained by efforts. Every tourist has travel motives. Swarbrooke \& Horner (1999) identified five main factors differentiate travel motivation: personality, lifestyle, past experience, perception, and image.

\section{Personality}

It is a complex of all the attributes, consists of behavioural, temperamental, emotional and mental, that characterize a unique individual. It is a person of considerable prominence, is he an active or passive tourist? Is she an adventurer or careful person? Is he an open-minded or a close-minded? Is she a planner or a go-show tourist?

\section{Lifestyle}

Lifestyle is a manner of living that reflects the person's values and attitudes. There are individuals who always want to experience differently from other people. There are individuals want to travel to fashionable destination. There is environmental friendly tourist. There are tourists who travelling to search novelty. There are people to want to meet other people, or having fun, or contemplate his or herself.

\section{Past Experience}

Most of tourist paid attention to past experience and it forebode the next travel planning. The positive past experience may bring people to repeat the trip, on the other hand, the previous negative incident may lead to unrepeated journey or even tourist will try to avoid the risk.

\section{Perception}

It is a way of tourist in conceiving something from the surrounding information. Perception in tourist mind describes the process whereby sensory stimulation is translated into organized experience. Perception is the effect of perceiving the promotional material from the tourism industry such as advertisement, tour package brochure, friend's recommendation, etc. Perception emerge the strength and the weakness of tourist motivation, the physical and the psychological set of tourist to travel.

\section{Image}

It is a representation of a something. It explains how a tourist wants to be seen and treated by others. Image is closely related with expectation. Positive image may drive tourist to visit the destination, on contrary, negative image may drive tourist away from destination. All above factors transform lined up with individual changes and trends, for example, if a woman has a family or meet her soul mate, or if there is a raise in income or a declining heath, the behaviour as tourist will change. 


\section{Conscious and Unconscious Motives of Travel}

Tourist motivation is a translation of tourist needs and wants. The feeling of dissatisfaction is the starting point and it comes from conscious and unconscious reasons. Lack of something forces a person to act and the action should aim to reach a particular expectation. If the expectation is met, the feeling of satisfaction comes to mind; the process of motivation is done but keep on cycling. Human never feel fully satisfied and they keep on searching for unlimited expectation. The dissatisfaction feeling is taken place by intrinsic and extrinsic motivation (Kotler, 2006). The intrinsic motivation comes from inside tourist's mind. It is the action which is essential and specific to that thing, and which is wholly independent of any other consequence. Often the intrinsic factors unconsciously push someone to do his or her activities beyond his or her ability. Some tourist prefers activities with the reasons for it are not available in the individual's conscious mind such as diving with dangerous sharks, bungee jumping without safe guard. Meanwhile the extrinsic motivation comes from outside environment. It provides satisfaction and pleasure that the task itself may not provide. The extrinsic motivation such as destination campaign is intentionally created by operator to activates and energizes tourist toward his or hers goal-oriented behaviour in travelling. It is consciously produced to motivate tourists.

The conscious and unconscious motivation can also fit to hierarchy of need (Cooper et.al., 2005; Ritchie \& Goeldner, 2003; Swarbrooke \& Horner, 1999; Mill, 1992; Ross, 1990). The basic assumptions of theory are: (1) human always has need which derives from dissatisfaction of past achievement; (2) the human needs can be compiled and arranged based of the hierarchy of importance. There are five stages of human needs which can be related to conscious and unconscious travel motives. Motivation allows tourist to make travel decision and the motives may be comprised from elements such as (1) tourism is the response of unfulfilled desire; (2) destination attraction is the reaction of the motivation; (3) motivation is a fantasy and a dream; (4) motivation always has purposes which end to satisfaction and dissatisfaction; (5) motivation and experiences are in separated; (6) motivation has its own meaning to every tourist. Those elements come from two strong determinants (Cooper, 2005), push factors and pull factors. The inner drives as push factors derive from psychological aspects or self-centred. Often it is unconscious motive. On contrary, the outer direct as pull factors explain why people travelling. The reasons can be varied such as novelty, exploration, social interaction, etc and mostly are conscious motive.

\section{METHODOLOGY}

As the research purpose is to reveal the main motives of travelling: inner intention as the unconscious motives and outer magnet as the conscious motives of Indonesian tourist, the framework of research is drawn in Figure 1.

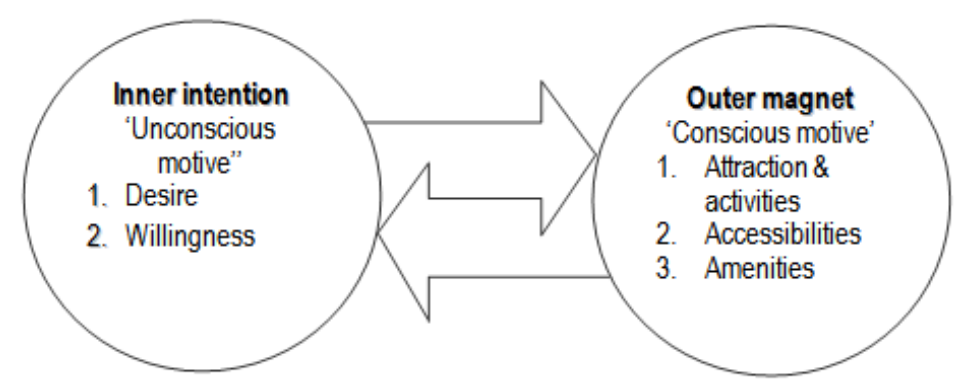

Figure 1 The Framework of Conscious and Unconscious Motives of Tourists' Preferences 
The variables of inner intention as unconscious motives (Cooper, 2005; Ritchie \& Goeldner, 2003; Ryan, 1997; Kotler, 2006) are as follows: (1) desire, there are psychological and physiological reasons that motivate people to travel, there are seven instinctive reasons to get away; (2) willingness, an opportunity to fulfil the desire, consists of: availability of leisure time and sufficient travel financial. Whilst, the variables of outer magnet as conscious motives (Cooper, 2005; Gunn, 1995; Page, 2007; Ritchie \& Goeldner, 2003; Ryan, 1997) are (1) attractions and activities such as naturebased, culture-based andspecial interest; (2) accessibilities such as the ease of transportation trip and distance; (3) amenities such as sophisticated facilities and well-equipped infrastructures. All endogenous and exogenous variables can be seen in table 2 .

Table 2 Research Operational Variables

\begin{tabular}{|c|c|c|}
\hline Motives & Exogenous Variables & Endogenous Variables \\
\hline $\begin{array}{l}\text { Inner intention as } \\
\text { Unconscious Motives }\end{array}$ & $\begin{array}{l}\text { Desire } \\
\text { Willingness }\end{array}$ & $\begin{array}{ll}\text { 1. } & \text { Excitement } \\
\text { 2. } & \text { Exploration } \\
\text { 3. } & \text { Health } \\
\text { 4. } & \text { Prestige } \\
\text { 5. } & \text { Religious } \\
\text { 6. } & \text { Self-improvement } \\
\text { 7. } & \text { Social interaction } \\
\text { 8. } & \text { Leisure time } \\
\text { 9. } & \text { Travel financial }\end{array}$ \\
\hline $\begin{array}{l}\text { Outer Magnet as } \\
\text { Conscious Motives }\end{array}$ & $\begin{array}{l}\text { Attractions \& activities } \\
\text { Accessibilities } \\
\text { Amenities }\end{array}$ & $\begin{array}{ll}\text { 1. Nature-based } \\
\text { 2. Culture-based } \\
\text { 3. Man-made } \\
\text { 4. Ease of transportation } \\
\text { 5. Trip intensity } \\
\text { 6. Distance } \\
\text { 7. Sophisticated facilities } \\
\text { 8. } & \text { Well-equipped infrastructures } \\
\end{array}$ \\
\hline
\end{tabular}

\section{Data and Methods}

Data and information are collected and compiled from two sources: primary data and secondary data. Primary data is composed from field survey using closed questionnaires, conducted in two cities, Jakarta and Bandung, in certain meeting point such as airports, train stations, hotels and tourist objects. Secondary data is the accumulation of information in form of statistical data, directory of tourist objects and amenities, and library research. The samples are the Indonesia citizen who has been travelling abroad at least once in a life time for the purpose of leisure. Random sampling methods have been used to obtain 331 respondents during school holidays (June and December 2008) and during off-peak seasons (March and September 2008).

The instruments were translated into Indonesian language or Bahasa. The respondents were asked to give their agreement or disagreement from 32 statements regarding conscious and unconscious motive (see table 2) on a five-point scale (totally disagree, disagree, no comment, agree, and totally agree). They were not requiringverbalizing their comments or expressing their feeling with the interviewer. The 32 statements were adopted from previous motivation theory (Page, 2007; Kotler, 2006; Cooper et.al, 2005; Ritchie and Goeldner, 2003; Ryan, 1997; Gunn, 1995). The research tool used is Structural Equation Modelling (or SEM) based on AMOS 7.0. It is required to have N $>100$ respondents (Garson, 2008). Therefore, the total samples of this research are met with the SEM requirement. There are five steps in SEM: (1) defining individual construct and developing the overall measurement model (path diagram); (2) design the study to produce empirical result. Value of an observed endogenous should be 1 and all value of unobserved exogenous variable is one; (3) assessing 
the measurement model validity using Confirmatory Factor Analysis (CFA); (4) specifying the structural model; (5) examine the structural model validity using the criteria of Goodness-of-fit (GOF) indices (Table 3).

Table 3 The Criteria of Goodness-of-fit (GOF)

\begin{tabular}{|c|c|c|}
\hline \multicolumn{2}{|c|}{ Measurement } & Parameter \\
\hline \multirow[t]{6}{*}{ Absolute Fit } & Chi-square & Lower is better. \\
\hline & & Positive and in between the range. \\
\hline & GFI & $\begin{array}{l}\text { Value of } 0 \text { to } 1 \text {, higher is better. GFI } \geq 0,90 \text { is good } \\
\text { fit; } 0,80-0,90 \text { is marginal fit. }\end{array}$ \\
\hline & RMR & $\mathrm{RMR} \leq 0,05$ is good fit. \\
\hline & RMSEA & RMSEA $\leq 0,08$ is good fit. \\
\hline & ECVI & $\begin{array}{l}\text { ECVI value of default model should be closed to } \\
\text { ECVI value of saturated model. }\end{array}$ \\
\hline \multirow[t]{6}{*}{ Incremental Fit } & TLI/NNFI & $\begin{array}{l}\text { Value of } 0 \text { to } 1 \text {, higher is better. TLI } \geq 0,90 \text { is good } \\
\text { fit; } 0,80-0,90 \text { is marginal fit. }\end{array}$ \\
\hline & NFI & $\begin{array}{l}\text { Value of } 0 \text { to } 1 \text {, higher is better. NFI } \geq 0,90 \text { is good } \\
\text { fit; } 0,80-0,90 \text { is marginal fit. }\end{array}$ \\
\hline & AGFI & $\begin{array}{l}\text { Value of } 0 \text { to } 1 \text {, higher is better. AGFI } \geq 0,90 \text { is good } \\
\text { fit; } 0,80-0,90 \text { is marginal fit. }\end{array}$ \\
\hline & RFI & $\begin{array}{l}\text { Value of } 0 \text { to } 1 \text {, higher is better. RFI } \geq 0,90 \text { is good } \\
\text { fit; } 0,80-0,90 \text { is marginal fit. }\end{array}$ \\
\hline & IFI & $\begin{array}{l}\text { Value of } 0 \text { to } 1 \text {, higher is better. IFI } \geq 0,90 \text { is good fit; } \\
0,80-0,90 \text { is marginal fit. }\end{array}$ \\
\hline & CFI & $\begin{array}{l}\text { Value of } 0 \text { to } 1 \text {, higher is better. CFI } \geq 0,90 \text { is good } \\
\text { fit; } 0,80-0,90 \text { is marginal fit. }\end{array}$ \\
\hline \multirow[t]{4}{*}{ Parsimonious Fit } & PGFI & $\begin{array}{l}\text { Positive value means economical fit. PGFI value of } \\
\text { default model should be higher than PGFI value of } \\
\text { saturated model. }\end{array}$ \\
\hline & PNFI & $\begin{array}{l}\text { Positive value means economical fit. PNFI value of } \\
\text { default model should be higher than PNFI value of } \\
\text { saturated model. }\end{array}$ \\
\hline & AIC & $\begin{array}{l}\text { Positive value means economical fit. AIC value of } \\
\text { default model should be closed to AIC value of } \\
\text { saturated model. }\end{array}$ \\
\hline & CAIC & $\begin{array}{l}\text { Positive value means economical fit. CAIC value of } \\
\text { default model should be closed to CAIC value of } \\
\text { saturated model. }\end{array}$ \\
\hline
\end{tabular}

Source: Ferdinand (2005:282)

\section{DISCUSSION}

\section{Findings - Respondents Profile}

Fifty-three percent $(53 \%)$ of respondents were women and 47 percents were men. Recently women traveller increase significantly worldwide and UNWTO predicts that number of women traveller will exceed men traveller since they become more independent and able to make their own decision. In Indonesia the proportion between women traveller and men traveller is 3 to 2 . The purposes of visit were mostly recreation ( 45 percents) and visiting friends and relatives (26 percent). 10 percent for business related purposes. The rest of the purpose of visit areeducation,sport and health. Twenty-eight percent $(28 \%)$ respondents used cars as the mode of transportation, 26 percent of respondent are travelled by bus, 22 percent are travelled by plane, 15 percent by train and the rest were used other mode of transportation such as motorcycle and ship. Cars were preferable since it is flexible and reach the out-reach destination. 
Fifty percent (50\%) of respondents were on vacation with family and friends. Family tourism is suitable with Indonesian tourist as it is a type of tourism where accommodation, meals, recreational activities and prices are specially adapted to suit the needs and comfort of families with children. Forty percent $(40 \%)$ of respondents stayed for 5 to 7 days and 34 percent of respondents are weekender. Length of stay is the key indicator of a successful tourism industry. The greater the length of stay, the greater the tourist will spend. The length of stay of respondents are varied but mostly were not more than a week. The decree of designating public holiday and collective leave can extend the duration. The average of length of stay is compatible with the average stay of 1 to 7 days based on Indonesian statistical data.

\section{The Influence of Unconscious Motives to Conscious Motives in Indonesian Tourist Preferences}

The influence of unconsicous motives toconscious motives in Indonesian tourist's preferences was drawn in the default model A (see Figure 2).

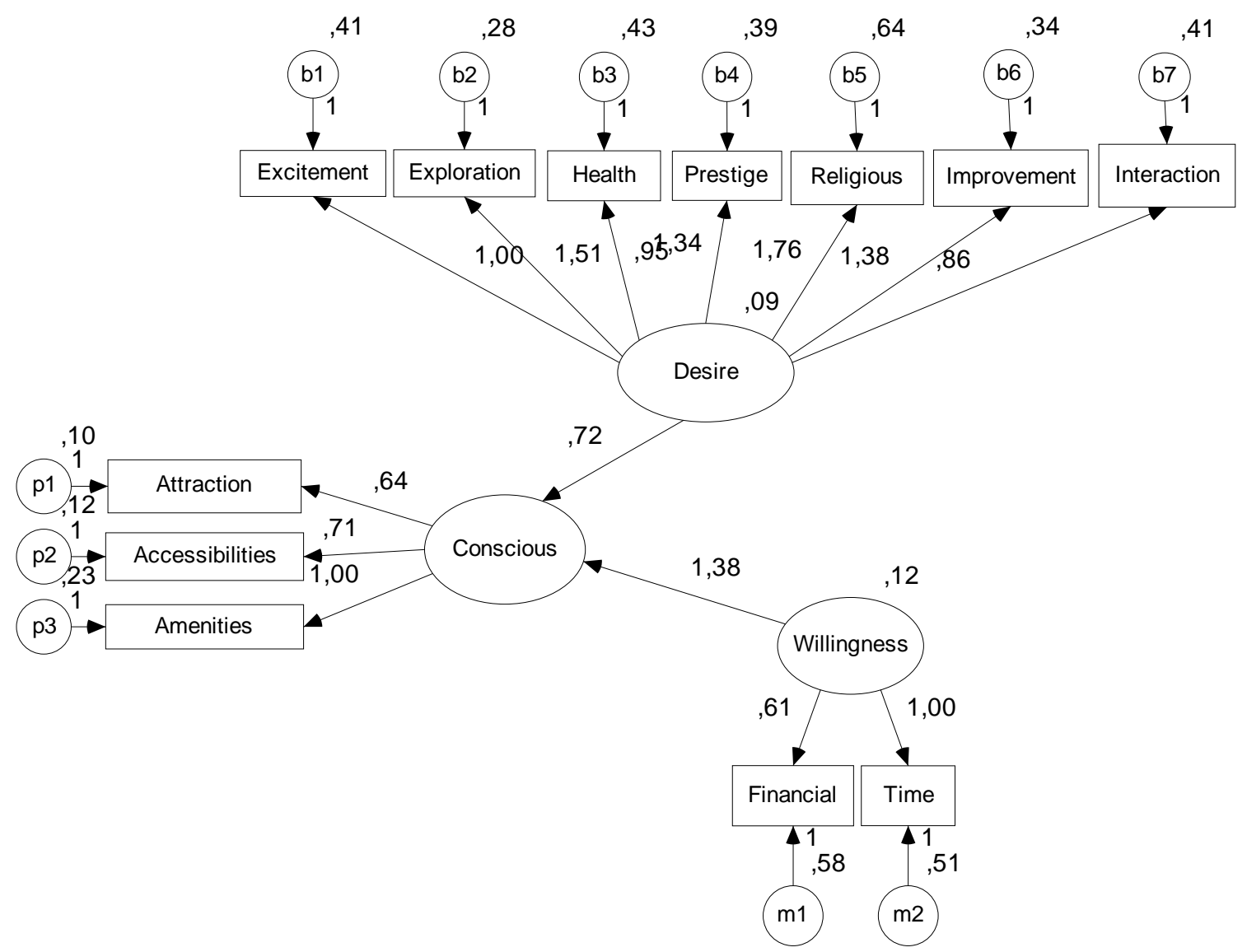

Source: Data Collection (2010)

Figure 2 Default Model A: The Effect of Unconscious Motives (Unobserved) to Conscious Motives in Tourist Preferences 
The result was examined by GOF and it indicated mostly Good (see table 4).

Table 4 GOF of Default Model A and Default Model B

\begin{tabular}{|c|c|c|c|c|c|}
\hline \multicolumn{2}{|c|}{ Measurement } & \multirow{2}{*}{$\frac{\text { Default model A }}{451,3}$} & \multirow{2}{*}{$\frac{\text { Analysis }}{\text { Good }}$} & \multirow{2}{*}{$\frac{\text { Default model B }}{261}$} & \multirow{2}{*}{$\frac{\text { Analysis }}{\text { Good }}$} \\
\hline Absolut Fit & Chi-square & & & & \\
\hline & Df & 53 & Good & 30 & Good \\
\hline & GFI & 0,826 & Good & 0,87 & Good \\
\hline & RMR & 0,089 & Good & 0,05 & Good \\
\hline & RMSEA & 0,15 & $\mathrm{Bad}$ & 0,152 & $\mathrm{Bad}$ \\
\hline & ECVI & $1,51($ Saturated model $=0,47)$ & Good & $0,937($ Saturated model $=0,331)$ & Good \\
\hline \multirow[t]{6}{*}{ Incremental Fit } & TLI/NNFI & 0,58 & Good & 0,758 & Good \\
\hline & NFI & 0,63 & Good & 0,824 & Good \\
\hline & AGFI & 0,75 & Good & 0,762 & Good \\
\hline & RFI & 0,55 & Good & 0,735 & Good \\
\hline & IFI & 0,66 & Good & 0,841 & Good \\
\hline & CFI & 0,66 & Good & 0,839 & Good \\
\hline \multirow[t]{5}{*}{ Parsimonious Fit } & PGFI & 0,56 & Good & 0,475 & Good \\
\hline & PNFI & 0,51 & Good & 0,549 & Good \\
\hline & AIC & $501,3($ Saturated $=156,0)$ & Good & $311($ Saturated $=110.0)$ & Good \\
\hline & CAIC & $621,5($ Saturated $=531,0)$ & Good & $431,2($ Saturated $=374,4)$ & Good \\
\hline & $\mathrm{CN}$ & 333 & Good & 333 & Good \\
\hline
\end{tabular}

Source: Data Collection (2010)

The findings as shown in table 5 were:

Table 5 The Effect of Unobserved Unconscious Motive To Conscious Motive

\begin{tabular}{lllccc}
\hline & & & Square multiple correlation & Correlation & Total Effect \\
\hline Conscious & $<---$ & Desire & 0,828 & 0,910 & 0,723 \\
Conscious & $<---$ & Willingness & 0,172 & 0,415 & 1,379 \\
Excitement & $<---$ & Desire & 0,185 & 0,430 & 1,000 \\
Exploration & $<---$ & Desire & 0,434 & 0,659 & 1,512 \\
Health & $<---$ & Desire & 0,164 & 0,404 & 0,950 \\
Prestige & $<---$ & Desire & 0,302 & 0,549 & 1,338 \\
Religious & $<---$ & Desire & 0,310 & 0,557 & 1,760 \\
Improvement & $<---$ & Desire & 0,341 & 0,584 & 1,383 \\
Interaction & $<---$ & Desire & 0,143 & 0,379 & 0,858 \\
Time & $<---$ & Willingness & 0,195 & 0,441 & 1,000 \\
Financial & $<---$ & Willingness & 0,074 & 0,272 & 0,611 \\
Amenities & $<---$ & Conscious & 0,555 & 0,745 & 1,000 \\
Accessibilities & $<---$ & Conscious & 0,546 & 0,739 & 0,712 \\
Attraction & $<---$ & Conscious & 0,543 & 0,737 & 0,639 \\
\hline
\end{tabular}

Source: Data Collection (2010)

It was estimated that the desires contributed 82,8 percents of its variance to conscious motive and 17,2 percent of the variance were influenced by other factors. Whereas willingness explain 17,2 percents of its variance to Conscious motive and 82,8 percent of the variance were induced by factors other than willingness. Desire plays a role in unconscious motive more than Willingness. Both desire and willingness had positive correlation. An estimate of the correlation between conscious and desirewas 0,910 and the correlation between conscious and willingnesswas 0,415 . It means that desire connected closer to conscious rather than willingness.

The total (direct and indirect) effect of willingness on conscious was 1,379. That was, due to both direct (unmediated) and indirect (mediated) effects of Willingness on Conscious, when willingness went up by 1 , conscious went up by 1,379 . The total (direct and indirect) effect of desire on consciouswas 0,723 . That is, due to both direct (unmediated) and indirect (mediated) effects of desire on conscious, when desire increased by 1 , conscious increased by 0,723 . 
Desire consists of seven's hidden elements (endogenous variables). Among all, there are two elements play major part in shaping desire as unconscious motive, religious and exploration. It was estimated that the predictors of religious contributed 31 percent of its variance to desire. In other words, the other factors were approximately 69 percent. Meanwhile, exploration explained 43,4 percent of its variance to desire and approximately 56,6 percent of the variance induced by other factors. Both religious and exploration had positive correlation with Desire. It was estimated that 0,557 was the correlation between religious and desire and 0,659 , was an estimate of the correlation between exploration and desire. The total (direct and indirect) effect of desire on religious was 1,760. That was, due to both direct (unmediated) and indirect (mediated) effects of desire on religious, when desire raise by 1 , religious raise by 1,76 . The total (direct and indirect) effect of desire on exploration is 1,512. That was, due to both direct (unmediated) and an indirect (mediated) effect of desire on exploration, when desire went up by 1 , exploration went up by 1,512 . It was estimated that time explained 19,5 percent of its variance to willingness and other factors contributed approximately 80,5 percent. Financial donated only 7,4 percent of its variance to Willingness whilst approximately 92,6 percent caused by other factors. Neither time nor financial gave significant contribution to willingness as Unconscious motive. The correlation between time and willingness was 0,441 and 0,272 was an estimate of the correlation between Financial and Willingness. It means that tourist considered time as the essential in his or her preference.

\section{The Impact of conscious Motives to Unconscious Motive in Indonesian Tourist Preferences}

Conversely, the impact of conscious motive to unconscious motive in tourist's preferences was drawn in the default model B (see figure 3).

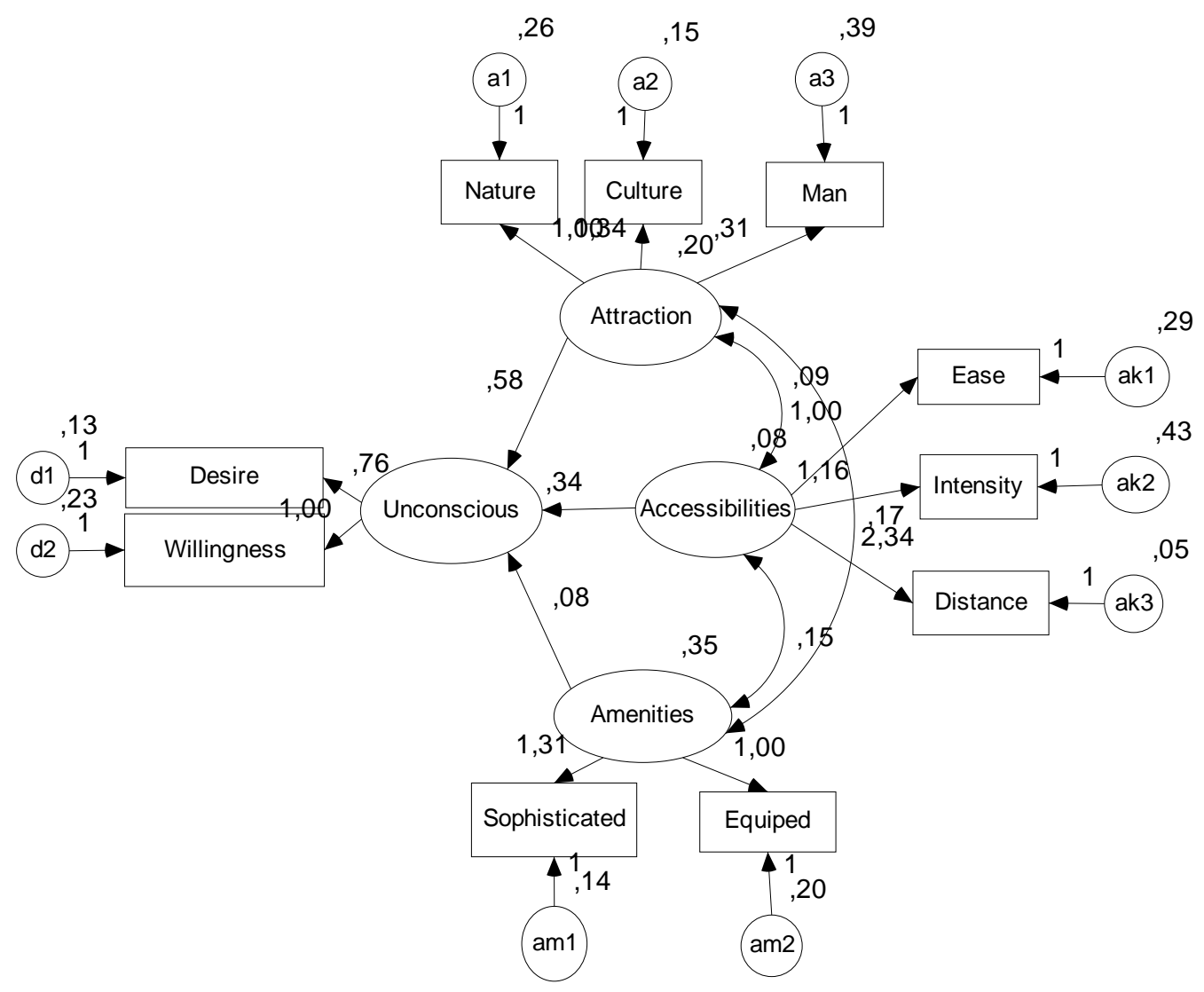

Figure 3 - Default Model B: The Impact of Conscious Motives (Unobserved) to Unconscious Motives in Tourist Preferences 
The model was examined by GOF and the result are mostly fit with the criteria (see table 4). Meaning, the default model can be accepted.

Table 6 The Impact of Unobserved Conscious Motive to Unconscious Motive

\begin{tabular}{|c|c|c|c|c|c|}
\hline & & & $\begin{array}{c}\text { Square multiple } \\
\text { correlation }\end{array}$ & Correlation & $\begin{array}{l}\text { Total } \\
\text { Effect }\end{array}$ \\
\hline Unconscious & $<---$ & Attraction activities & 0,921 & 0,960 & 0,584 \\
\hline Unconscious & $<---$ & Accessibilities & 0,755 & 0,849 & 0,340 \\
\hline Unconscious & $<---$ & Amenities & 0,635 & 0,797 & 0,080 \\
\hline Nature-based & $<---$ & Attraction activities & 0,436 & 0,660 & 1,000 \\
\hline Culture-based & $<---$ & Attraction activities & 0,701 & 0,837 & 1,341 \\
\hline Man-made & $<---$ & Attraction activities & 0,046 & 0,214 & 0,307 \\
\hline Ease of transportation & $1<---$ & Accessibilities & 0,218 & 0,466 & 1,000 \\
\hline Trip Intensity & $<---$ & Accessibilities & 0,202 & 0,499 & 1,158 \\
\hline Distance & $<---$ & Accessibilities & 0,892 & 0,944 & 2,336 \\
\hline Well-equipped & $<---$ & Amenities & 0,638 & 0,799 & 1,000 \\
\hline Sophisticated & $<---$ & Amenities & 0,815 & 0,903 & 1,313 \\
\hline
\end{tabular}

Attraction and activities contributedthe most to unconscious motives. It was estimated that 92,1 percent of attraction and activities' variance was donated to unconscious motives, and 7,9 percents of the variance is donated by other factor. 0,960 was an estimate of the correlation between unconscious and attractions activities, which means that there was a positive connection. The total (direct and indirect) effect of attraction on unconscious motives was 0,584. That was, due to both direct and indirect effect of attraction on unconscious motives, when attraction increased by 1 , unconscious increased by 0,584 .

Unconscious motive was also induced by accessibilities. It was estimated that the predictors of accessibilities explained 75,5 percents of its variance and it is approximately 24,5 percent of other factors. The correlation between unconscious and accessibilities was estimated 0,849 . In other words, there was a positive relation between these two.The total (unmediated and mediated) effect of accessibilities on unconsciouswas 0,340 . That was, due to both unmediated and mediated effects of accessibilities on unconscious, when accessibilities raised by 1 , unconscious raised by 0,34 .

The amenities contributed 63,5 percents of its variance to tourist's unconscious motives and the other factors was approximately 36,5 percents. Thus, it can be said that the impact of amenities in tourist's unconscious motives was 63,5 percents. 0,797 was an estimate of the correlation between unconscious and amenities. Meaning, the relation between unconscious and amenities was positive. The total (direct and indirect) effect of amenities on unconscious was 0,080 . That was, due to both direct (unmediated) and indirect (mediated) effects of amenities on unconscious, when amenities went up by 1 , Unconscious went up by 0,08 .

Attractions and activities consisted of three hidden elements: nature-based, culture-based and man-made based. Among these three, culture-basedgave the biggest contribution to attractions and activities variable. Culture-based gave 70,1 percentsto attractions and activities, the other factor was approximately 29,9 percents. Meaning, Indonesian tourist's preferences wasunconsciously motivated the most by culture-based attractions and activities. 0,837 was an estimate of the correlation between culture and attractions. The total (direct and indirect) effect of attraction on culturewas 1,341. That was, due to both direct (unmediated) and indirect (mediated) effects of Attraction on Culture, when Attractionincreased by 1 , cultureincreased by 1,341 . 
Accessibilities comprised of three unobserved variables: ease of transportation, trip intensity and distance. Among those, distance was the highest contribution to accessibilities. It was estimated that the predictors of distance explained 89,2 percent of its variance whilst 10,8 percent from other factors. In other words, Indonesians intentionally consider distance as their preference. The total (direct and indirect) effect of accessibilities on distance was 2,336. Meaning, due to both direct (unmediated) and indirect (mediated) effects of accessibilities on distance, when accessibilities went up by 1 , distance went up by 2,336.An estimate of the correlation between distance and amenities was 0,944 meaning there was a positive relationship.

Amenities contained two unseen variables: sophisticated facilities and well-equipped facilities. Among those two variables, sophiscated facilities was the most contributed to amenities. It was estimated that the predictors of sophisticated facilities explained 81,5 percent of its variance and 18,5 percent was other factors. It meant that Indonesian overlook sophisticated facilities as their conscious motives. The correlation between sophisticated facilities and amenities was 0.903 . Meaning, there was a positive link between sophisticated facilities and amenities. The total effect of amenities on sophisticatedfacilities was 1,313. In the other words, when amenitiesincreased by 1 , sophisticatedfacilities increased by 1,313 .

\section{CONCLUSION}

This research exploredtwo motives of travelling: inner intention as the unconscious motives and outer magnet as the conscious motives that influence Indonesian tourist preferences. Inner intentions derived from tourist itself and pushed his or her to travel. Outer magnet was created by destination and attracted the customers. From 331 respondents in Jakarta (capital city) and Bandung as tourist generating regions in Indonesia showed that there was partial element of inner intention that encouraged Indonesian to travel: religiousness and leisure time. Both were hidden variables of unconscious motive. Each variable (religious and leisure time) independently brought direct and indirect impact to unconscious motive. Most of tourist was unaware that their preferences were affected by religiousness and time.

In the other hand, there were collective elements of outer magnet that attracted Indonesian tourist: cultural attractions and activities, distances, and sophisticated amenities. All those are unobserved variable of conscious motive and jointly gave impacts (directly and indirectly) to conscious motive. When Indonesian tourists want to make a travel decision, cultural attractions and activities, distances and sophisticated facilities will affect the preferences. Those findings can be used as basic consideration in creating a tour package targeted Indonesia tourists. The tour operator should deliberate the unconscious motive (desire and willingness separately) and the conscious motives (attractions activities, accessibilities and amenities at once).

In every holiday package offered to Indonesian, religious aspect is in main attention. For instance, the itinerary includes religious services, the meals prepare based on religious approach. Halal label is important. Any attractions and activities relating with culture and combine with religious issue catch the attention of Indonesia tourist or cultural religious festive such as, celebration of Prophet Muhammad, cremation of Hindus. Packages are offered in appropriate travel season (time). Tour operator must aware of public holiday and collective leave in calendar every year. High season in Indonesia is June-July (school holiday) and celebration after fasting month (Idul Fitri). Package in destination with sophisticated facilities and moderate travel distance will be the advantages. Indonesian tourists prefer short-haul and a stylish fashionable resort. They want to buy all-in-one stop package tour to an integrated destination. 


\section{REFERENCES}

BPS. (2009). Data Statistik Kunjungan Wisatawan Domestik. Jakarta: Biro Pusat Statistik.

Cooper, et. al. (2005). Tourism Principles and Practice (3rd ed.). London: Pitman Publishing.

Garson, G. D. (2008). Structural Equation Modelling, from http://www2.chass.ncsu.edu/garson/pa765/ structur.htm

Gee, C. Y. (1997). International Tourism: A Global Perspective (2nd ed.). Madrid: WTO.

Gunn, C. (1995). Tourism Planning (2nd ed.). New York: Routledge.

Kotler, P. (2006). Marketing for Hospitality and Tourism (3rd ed.). New Jersey: Prentice-Hall.

Mill, R. C. (1992). The Tourism System: an Introductory Text (2nd ed.). New Jersey: Prentice-Hall.

Pusat Pengelolaan Data dan Sistem Jaringan (P2DSJ). (2009). Buku Saku Pariwisata Indonesia. Jakarta: Depbudpar.

Ritchie, J. R. B. \& Goeldner, C. R. (2003). Tourism: principles, practices, philosophies. New Jersey: John Wiley and Sons, Inc.

Ross, G. F. (1990). The Psychology of Tourism. Melbourne: Melbourne Press.

Ryan, C. (ed.). (1997). The Tourist Experience: a New Introduction. London: Cassell.

Swarbrooke, J., \& Horner, S. (1999). Consumer Behaviour in Tourism. Oxford: ButterworthHeinemann. 